\title{
A proposed order-level classification in Oligochaeta (Annelida, Clitellata)
}

\author{
RÜDIGER M. SCHMELZ1*, CHRISTER ERSÉUS², PATRICK MARTIN, \\ TON VAN HAAREN ${ }^{4} \&$ TARMO TIMM ${ }^{5}$ \\ ${ }^{1}$ IfAB, Institute for Applied Soil Biology, Tomberg 24a, 22337 Hamburg, Germany. \\ ”. ruediger.schmelz@ifab-hamburg.de; ruedigermschmelz@gmail.com; @ https://orcid.org/0000-0001-7201-6771 \\ ${ }^{2}$ University of Gothenburg, Department of Biological and Environmental Sciences, Box 463, SE-405 30 Göteborg, Sweden. \\ "'christer.erseus@bioenv.gu.se; — https://orcid.org/0000-0002-9251-4046 \\ ${ }^{3}$ Royal Belgian Institute of Natural Sciences, Taxonomy and Phylogeny, 29 rue Vautier, B-1000 Brussels, Belgium \\ ”patrick.martin@naturalsciences.be; @ https://orcid.org/0000-0002-6033-8412 \\ ${ }^{4}$ Eurofins/Aquasense, H.J.E. Wenckebachweg 120, 1114 AD Amsterdam-Duivendrecht, Netherlands \\ "TonVanHaaren@eurofins.com; - i https://orcid.org/0000-0001-5119-1714 \\ ${ }^{5}$ Estonian University of Life Sciences, Centre for Limnology, EE-61117 Rannu, Tartumaa, Estonia \\ झ"tarmo.timm@emu.ee; @ https://orcid.org/0000-0003-4766-1976 \\ *Corresponding author
}

\begin{abstract}
The purpose of our contribution is to propose a robust and practical order-level classification of the families of Oligochaeta, that is, non-leech Clitellata. The order level is mandatory in Linnaean rank-based classification and is also required in many internet-based biodiversity databases. However, it has received little attention in oligochaete systematics, and the few available order-level classifications of Oligochaeta no longer represent phylogenetic relationships adequately. Our proposal is based on corroborated molecular phylogenetic evidence and takes as benchmarks class level for Clitellata, subclass level for Oligochaeta and Hirudinea, and order level for Crassiclitellata, the monophylum that includes most of the earthworm taxa. As a result, eleven orders are proposed: Alluroidida Timm \& Martin, 2015; Capilloventrida Timm, n. ordo; Crassiclitellata Jamieson, 1988; Enchytraeida Kasprzak, 1984; Haplotaxida Brinkhurst \& Jamieson, 1971; Lumbriculida Brinkhurst \& Jamieson, 1971; Moniligastrida Brinkhurst \& Jamieson, 1971; Narapida Timm, n. ordo; PARvidrilida Timm, n. ordo; Randiellida Jamieson, 1988; Tubificida Jamieson, 1978. This order-level classification is robust and easily adaptable to future insights into phylogenetic relationships.
\end{abstract}

Key words: Linnaean classification, order-level taxa, taxonomy, earthworms, aquatic oligochaetes

\section{Introduction}

Within the phylum Annelida, three major groups have traditionally been recognized, Polychaeta Grube, 1850, Oligochaeta Grube, 1850, and Hirudinea Savigny in Lamarck, 1818. From a phylogenetic point of view, Oligochaeta represents a derived lineage within Polychaeta (Struck et al. 2011), and the hirudineans have evolved from oligochaete ancestors (Michaelsen 1919). Hence, in phylogenetic classifications the first two groups are usually dismissed as paraphyletic; in handbooks and databases, however, Oligochaeta and Polychaeta are still maintained, from a perspective of evolutionary classification, or for reasons of practicality and tradition. Universally accepted is Clitellata (Michaelsen 1919), a monophyletic taxon that includes Hirudinea and all oligochaete taxa.

Oligochaeta was erected as an order (Grube 1850) and remained so for decades (e.g., Udekem 1855; Claparède 1862; Vejdovský 1884; Beddard 1895; Michaelsen 1900, 1928; Stephenson 1930), with few exceptions (class level in Benham 1890 and Avel 1959). Its elevation to subclass level, below class Clitellata, by Brinkhurst and Jamieson (1971) was influential and widely followed. In contrast, the corresponding attempts of an order-level classification of subtaxa of Oligochaeta above family level (Avel 1959; Brinkhurst \& Jamieson 1971; Brinkhurst 1982a,b; Timm 1981; Jamieson 1988) have remained controversial, and often the order level was simply ignored by systematists of Clitellata. 
However, the order level is mandatory in Linnaean rank-based classification and is also required in taxonomic databases such as WoRMS (2021). Hence, the purpose of our contribution is to propose a robust and acceptable order-level classification of the families of Oligochaeta (= oligochaetous Clitellata), following three criteria: (1) We present order-level taxa that are monophyletic, as far as we know, and we accept non-monophyletic taxa only when the phylogenetic relationships are still unresolved. We attempt to represent as far as possible the most recent insights into Clitellata phylogeny (Erséus et al. 2020 and references therein). (2) The orders are supposed to represent meaningful and recognizable taxa. (3) We respect the general classificatory scheme of class Clitellata with subclasses Oligochaeta and Hirudinea such as appears in many internet sources on taxonomy or biodiversity (e.g., EoL, ERMS, wikispecies, WoRMS, see also Ruggiero et al. 2015a,b).

Our approach is motivated by the concern to deal with a situation that has become untenable given the most recent knowledge of phylogenetic relationships within Clitellata, and to take into account the requirements of current taxonomic databases. Our purpose here is therefore practical and not meant to cast the fine-grained phylogenetic branching pattern of Clitellata into a Linnaean hierarchical classificatory framework (comp. Jamieson 1988; see also Dubois et al. 2021). Actually, we have different opinions considering a future classification. Some of us hold that a phylogenetic classification should integrate the whole of Annelida, i.e., take into account the nested position of Clitellata within a subgroup ("Sedentaria", Struck et al. 2011) of what still is named "Polychaeta" in spite of its evidently paraphyletic status, and that likewise "Oligochaeta" should be eliminated or considered synonymous with Clitellata. Others hold that Linnaean ranks are useful only in an evolutionary classification that allows paraphyletic groups, and that phylogenetic classification, to be effective, should abandon Linnaean ranks. That said, we all share an urge to resolve the problem of lacking an order-level classification of oligochaete Clitellata.

\section{Historical account}

The name Oligochaeta was first introduced by Grube (1850), for an order consisting of two families: Lumbricina and Naidea. Udekem (1855) and several subsequent authors accepted in general the taxon established by Grube, although sometimes with non-latinized names, while the number of families grew gradually. Oligochaeta was treated as a single order also in the monographs by Vejdovský (1884) and Beddard (1895). Michaelsen (1900) and Stephenson (1930) accepted the ordinal rank of Oligochaeta only by default, while dividing the group into (already numerous) families.

Michaelsen (1919) coined the class Clitellata, containing the two orders Oligochaeta and Hirudinea. Later, he subdivided Oligochaeta into the suborders Archioligochaeta (mostly small aquatic worms with chaetae variable in shape and number per bundle) and Neoligochaeta (mainly the earthworms plus some other taxa, all with simple, sigmoid and usually paired chaetae) (Michaelsen 1921). Ude (1929) rejected these two names referring to their unproven evolutionary sequence. Michaelsen's dichotomous division of Oligochaeta was last used by Chekanovskaya (1981), who called the two orders Naidomorpha and Lumbricomorpha.

Later, Michaelsen (1929) suggested an alternative classification based on differences in the male reproductive apparatuses, in particular the position of the male pores in relation to the testes. This led to three suborders, named Oligochaeta plesiopora, Oligochaeta prosopora, and Oligochaeta opisthopora. The first group included the majority of smaller, often aquatic, oligochaetes with male pores in the segment behind the testis segment (the "plesiopore" condition); the second consisted of the single, aquatic, family Lumbriculidae, with male pores within the testis segment ("prosopore" condition); and the third group comprised the earthworms plus a few aquatic taxa, with male pores several segments posterior to the testis segment(s) ("opisthopore" condition). Stephenson (1930: 718ff.) considered these attempts to classify Oligochaeta above the family level unnecessary and not sufficiently backed by phylogenetic evidence; he listed the families directly below the order Oligochaeta without intergrading ranks. Avel (1959) accepted Michaelsen's (1929) version with modifications: Oligochaeta was raised to a class, the suborders to orders, and the plesiopore group was subdivided, based on differences in the position of the spermathecae, leading to four orders, in scientific French: Plésiopores plésiothèques, Plésiopores prosothèques, Prosopores, and Opisthopores (Avel 1959). It should be noted that these classifications were meant to represent phylogenetic relationships, albeit not in a cladistic, Hennigian sense.

Brinkhurst (1971, 1982a,b, 1984) proposed a phylogenetic scenario of oligochaete taxa based on a hypothesized octogonadal ancestor with a plesiopore male reproductive system. ("Octogonadal" means two pairs of testes and 
two pairs of ovaries in four consecutive segments.) From this condition, still present in some species of Haplotaxidae, all other conditions were considered to be derived. Based on this scenario, the first classification (Brinkhurst \& Jamieson 1971; Brinkhurst 1982a) united all plesiopore and opisthopore taxa (i.e., those with male pores at least one segment posterior to the testes) in one order, Haplotaxida. It contained the bulk of all oligochaetes, small and large, aquatic and terrestrial. Two further orders were created for species with prosopore male pores (i.e., male pores and testes in the same segment), these were the aquatic Lumbriculida and the terrestrial Moniligastrida; the latter are earthworm-like forms much different from Lumbriculida. Later, Brinkhurst $(1982 b, 1984)$ reorganized the oligochaete taxa in four orders, Haplotaxida (now containing only Haplotaxidae), Lumbriculida (as before, with the single family Lumbriculidae), Tubificida (the bulk of small aquatic oligochaetes plus the amphibious Enchytraeidae), and Lumbricida (all earthworms plus Moniligastrida and the only opisthopore aquatic family, the Alluroididae). As a sidenote, Aeolosomatidae was excluded from Oligochaeta by Brinkhurst (1982b).

Timm (1981) also proposed a four-order classification of oligochaetes (without aeolosomatids, branchiobdellidans and leeches): Tubificida (corresponding to Naidomorpha sensu Chekanovskaya), Haplotaxida [consisting of Haplotaxidae, Alluroididae and the numerous earthworm families later recognized as the monophylum Crassiclitellata (Jamieson 1988)], Moniligastrida and Lumbriculida (both with a single, nominate family). This was a combination of the systems of Brinkhurst and Jamieson (1971) and Chekanovskaya (1981). The leading hypothesis here was that the tubificidan ("naidomorph") line with their diverse chaetae could not have descended from haplotaxid-like ancestors with paired chaetae, the latter considered as a synapomorphy of the "lumbricomorph" groups. Kasprzak (1984) adopted Timm's proposal but placed two families, Enchytraeidae and Dorydrilidae, into respective orders of their own.

Jamieson (1988) presented and discussed in full detail a phylogenetic classification using Linnaean ranks. The underlying tree was the result of a morpho-cladistic analysis. The large asymmetry of the tree resulted in a high number of ranks, including subclasses, superorders, suborders, cohorts and superfamilies, which are not covered here. The number of orders in Jamieson's system reached five: (1) Randiellida, with a single genus of uncertain position, and in sister-group position to the rest of the clitellates (as sub-class Randiellata), (2) Tubificida, including the bulk of aquatic families (then: Capilloventridae, Phreodrilidae, Tubificidae, Naididae, Opistocystidae, Dorydrilidae) and the Enchytraeidae, (3) Lumbriculida, (4) Moniligastrida, and (5) Opisthopora (Alluroidina plus Crassiclitellata, the latter including most of the earthworm families). The families Haplotaxidae and Tiguassidae were united in a presumably paraphyletic superorder Haplotaxidea, but an order rank taxon was not erected. Later, the same author integrated new insights of molecular phylogenetic analyses (Jamieson 2006) and presented a revised cladistic classification of Clitellata with indentations and symbols instead of Linnaean ranks to represent the hierarchy of taxa (ibid.: 260ff.). In a following chapter (ibid., 293 ff.), four orders were recognized, Tubificida, Haplotaxida sensu stricto, Moniligastrida, and Opisthopora; order level was not assigned to Randiellata and Lumbriculata, the latter a taxon with Lumbriculidae and Hirudinea as sister groups (Jamieson 1988).

Curiously, it was the three-order system (Brinkhurst \& Jamieson 1971; Brinkhurst 1982a) that was used in databases like WoRMS (2021), where the order level is mandatory. However, this system is impractical and outdated. It unites many divergent families into one mega-order Haplotaxida, with the subsequent need to create sub-ranks such as suborders and super-families. Furthermore, it no longer represents phylogenetic relationships adequately (see below); this, however, is also true of the other proposals (Chekanovskaya 1981; Timm 1981; Brinkhurst 1982b, 1984; Kasprzak 1984; Jamieson 1988; Jamieson 2006). Modern authors usually ignore the order level and the corresponding taxa, such as Haplotaxida sensu Brinkhurst \& Jamieson (1971); oligochaetes under study are introduced as, for example, "Oligochaeta: Naididae" (Corbi et al. 2015) or "Annelida, Clitellata, Tubificinae" (Ohtaka \& Martin 2011). In general, the family level has always been less problematic and more explanatory than the order level in oligochaetous Clitellata.

\section{Results and discussion}

Molecular phylogenetic studies have greatly advanced our understanding of the phylogenetic relationships of oligochaete taxa. Figure 1 illustrates the current understanding of phylogenetic relationships among families of oligochaetous Clitellata, based on a recent phylogenomic study (Erséus et al. 2020). With the exception of Haplotaxidae, all families shown are currently considered as monophyletic, and so is Crassiclitellata, the taxon that includes the 
numerous families of true earthworms (21 families in Magalhães et al. 2021, not listed here). Our proposal of orderlevel taxa in Oligochaeta is based on this tree, with the accepted order-level of Crassiclitellata as benchmark. The proposal is further conditioned by the asymmetric tree topology and the derived position of Crassiclitellata, which together leads to a system where each order comprises not more than one or two families. As a sidenote, it should not go unnoticed that the tree in Erséus et al. (2020) neatly reflects the early concept of Archioligochaeta and Neoligochaeta (Michaelsen 1921, 1928), with the latter nested in the former.
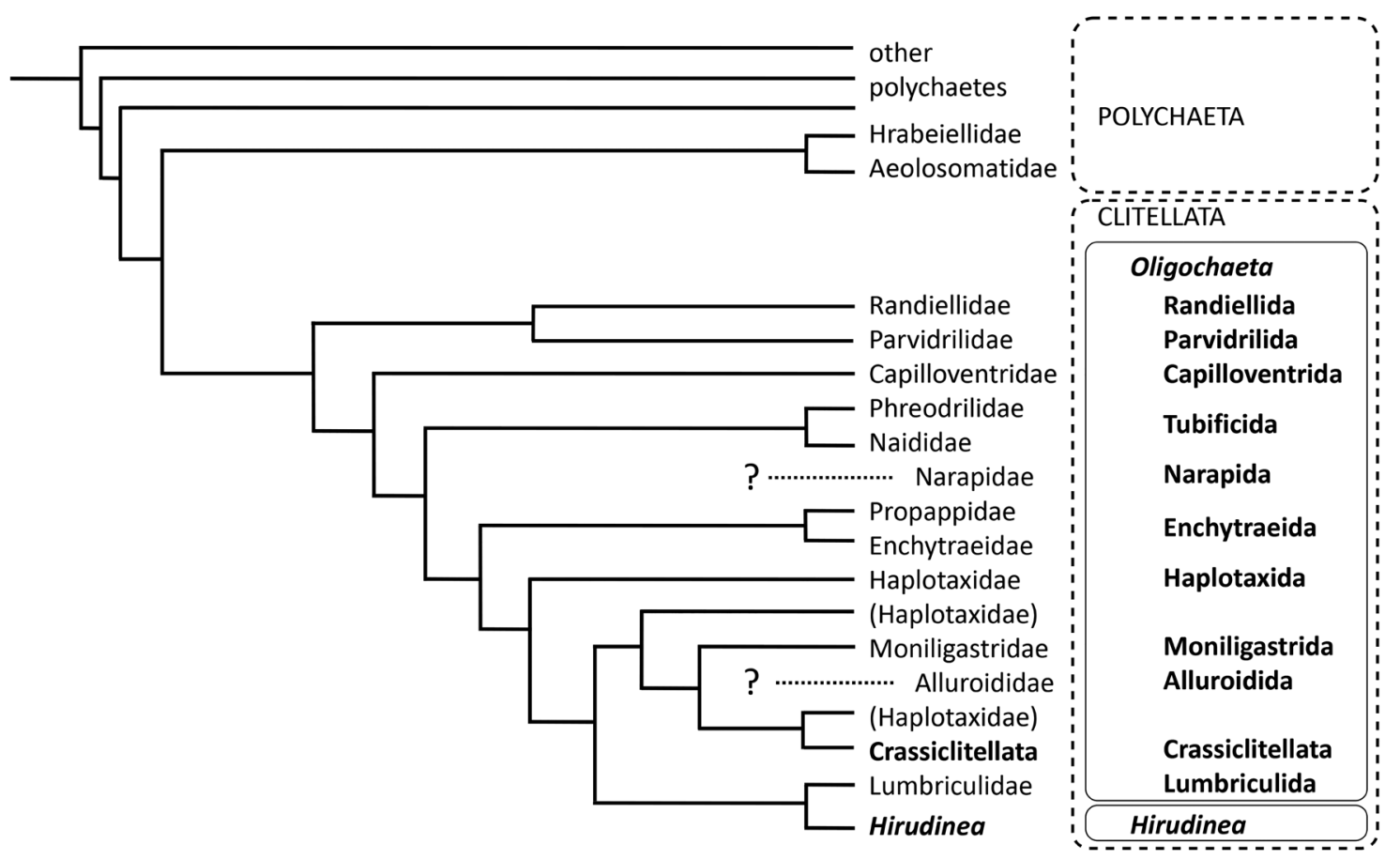

FIGURE 1. Phylogenetic relationships of families of Oligochaeta (=oligochaetous Clitellata), schematized after Erséus et al. (2020), and corresponding proposals of order-level taxa, printed in bold regular. Taxa with question mark were not investigated in Erséus et al. (2020) for lack of DNA data. Broken line boxes and words in capital letters: class level, continuous line boxes and words in bold italics: subclass level. The polyphyletic Haplotaxidae appears three times; the name without brackets represents the position of the type species, Haplotaxis gordioides (Hartmann in Oken, 1819). For further explanations, see text.

Closely related to Crassiclitellata are five families, Moniligastridae, Alluroididae, Haplotaxidae, Tiguassuidae, and Syngenodrilidae. The latter two are not shown in Fig. 1. Haplotaxidae is polyphyletic (Erséus et al., 2020) and will be split into different families (Martinsson et al., forthcoming). Closely related to Haplotaxidae is the monospecific Tiguassidae, but DNA data are not yet available. Moniligastridae are earthworms that lack the opisthoporous male pore condition and also a multi-layered clitellum, the latter an apomorphy of Crassiclitellata. Alluroidids are opisthoporous aquatic worms, similar in other respects to some taxa of Haplotaxidae; each is placed in an order of its own here. Syngenodrilidae, representing one species, which itself was described on a single specimen (Smith \& Green 1919), has been associated with either Moniligastridae (Stephenson 1930) or Alluroididae (Michaelsen 1928; Brinkhurst \& Jamieson 1971). Molecular data of Alluroididae and Syngenodrilidae are lacking; the latter is provisionally included in Alluroidida here.

Lumbriculidae, a species-rich group of prosoporous aquatic oligochaetes, is the sister-group of Hirudinea (Martin 2001), the latter a taxon considered to include three orders, the true leeches, named Hirudinida (Siddall et al. 2001), and the leech-like Acanthobdellida and Branchiobdellida; the latter was previously accommodated in Oligochaeta. The fact that taxa of different rank are sister-groups (order Lumbriculida and subclass Hirudinea) is odd from a perspective of phylogenetic (= cladistic) classification but acceptable in evolutionary classification (see Mayr \& Ashlock 1991: 122), and maintained here for practical reasons. Included in Lumbriculida is the monotypic Dorydrilidae, a doubtful family with close but unresolved relationships to Lumbriculidae. Hrabě (1984) includes Dorydrilus in Lumbriculidae, a view supported by molecular data (Achurra et al., forthcoming). 
Enchytraeidae is a species-rich and ubiquitous taxon whose monophyly has been confirmed (Erséus et al. 2010a). The few species of the monotypic Propappidae were initially considered as primitive aquatic members of Enchytraeidae (Michaelsen 1916, 1928) but later accommodated in a family of their own (Coates 1986). The sistergroup relationship of Propappidae and Enchytraeidae (Marotta et al. 2008) does not have strong molecular support (Erséus et al. 2020) but both families share a distinctive character, an extreme forward-shift of the spermathecae. As a sidenote, this character was reflected in Avel's (1959) "Plésiopores prosothèques" (italics by us).

Naididae as represented in Fig. 1 is a mega-taxon of aquatic oligochaetes, result of the fusion of the two species-rich families Naididae and Tubificidae into one family after recognizing that the former was polyphyletic, the latter paraphyletic, and that both together are monophyletic (Envall et al. 2006); the new comprehensive family, into which later the species-poor Opistocystidae were fused as well (Erséus et al. 2010b), received the name Naididae for reasons of nomenclature (Erséus et al. 2008). However, some systematists maintain Tubificidae in their traditional circumscription and accommodate the rest of Naididae sensu Erséus et al. (2008) in four different families (see below). The sister-group relationship of Phreodrilidae and Naididae s.l. (i.e., sensu Erséus et al. 2008) is supported by similarities of the male reproductive apparatuses.

Three small aquatic oligochaete families, each with a single genus, are very different genetically and in the structure of their reproductive system, and they are now considered as derived from the ancient clitellate stem (Erséus et al. 2020): Capilloventridae, Parvidrilidae (both bearing dorsal hair chaetae like most Tubificida, but also ventral, a unique feature among oligochaetes) and Randiellidae (externally resembling Enchytraeidae). The monospecific family Narapidae is another taxon of unclear position; it has simple genitalia (possibly a derived feature) and lacks chaetae, but molecular data are unknown. Each of these families deserves establishment of a separate nominal order, which so far has been formally proposed only for Randiellidae (Jamieson 1988). We suggest order level also for Parvidrilidae, even though it may form a monophyletic group with Randiellidae (see Erséus et al. 2020, p. 625); both families are very different in the reproductive structures and chaetal equipment (comp. Erséus \& Strehlow 1986; Martínez-Ansemil et al. 2012).

Proposal of order-level classification of Oligochaeta. In formal faunistic databases such as WoRMS; World Distribution of the Aquatic Oligochaeta (Timm 2021), etc., one must find all taxa in their "boxes" at the main levels of the taxonomic hierarchy. We propose the following, practical system of the subclass Oligochaeta (= oligochaetous Clitellata) with 11 orders (in alphabetic order here), most of them consisting of small and aquatic worms. The numerous families of the order Crassiclitellata (majority of the earthworms, see James \& Davidson 2012; Magalhães et al. 2021), are not listed here. Dates of authorship of some families have recently been corrected (Van Haaren et al. 2021), following the rules of ICZN (1999). At the order level, where the rules of ICZN do not apply, authorship and date refer to the reference where, to the best of our knowledge, for the first time a taxon has been erected at order level with the spelling as given below.

Alluroidida Timm \& Martin, 2015

Family Alluroididae Michaelsen, 1900 (amphibious, mainly freshwater)

Family Syngenodrilidae Smith \& Green, 1919 (terrestrial?; one genus, one species)

Capilloventrida Timm, n. ordo

Family Capilloventridae Harman \& Loden, 1984 (freshwater, marine)

Crassiclitellata Jamieson, 1988

at least 21 families of true earthworms (mostly terrestrial)

Enchytraeida Kasprzak, 1984

Family Propappidae Coates, 1986 (freshwater)

Family Enchytraeidae d'Udekem, 1855 (mostly terrestrial, also freshwater, marine)

Haplotaxida Brinkhurst \& Jamieson, 1971

Family Haplotaxidae Michaelsen, 1900 (freshwater, polyphyletic)

Family Tiguassidae Brinkhurst, 1988 (freshwater, one genus, one species) 
Lumbriculida Brinkhurst \& Jamieson, 1971

Family Lumbriculidae Claus, 1872

(including also the former Dorydrilidae Cook, 1968 - mostly freshwater; sister group of the subclass Hirudinea Savigny in Lamarck, 1818; the latter with orders Acanthobdellida Livanow, 1905, Branchiobdellida Holt, 1963 and Hirudinida Siddall et al., 2001)

Moniligastrida Brinkhurst \& Jamieson, 1971

Family Moniligastridae Claus, 1880 (terrestrial and earthworm-like)

Narapida Timm, n. ordo

Family Narapidae Righi \& Varela, 1983 (freshwater, one genus, one species)

Parvidrilida Timm, n. ordo

Family Parvidrilidae Erséus, 1999 (freshwater, one genus)

Randiellida Jamieson, 1988

Family Randiellidae Erséus \& Strehlow, 1986 (marine, one genus)

Tubificida Jamieson, 1978

Family Naididae Ehrenberg, 1831

*Family Pristinidae Lastočkin, 1921

*Family Opistocystidae Černosvitov, 1936

*Family Tubificidae d'Udekem, 1855

Family Phreodrilidae Beddard, 1891

* included in Naididae s.l. in phylogenetical classification (see Erséus et al. 2008)

Side note. As a result of literature studies, authorship of the following taxon names was changed as follows (see also Van Haaren et al. 2021): Hirudinea Savigny in Lamarck, 1818, previously cited as Hirudinea Lamarck, 1818 or Savigny, 1822. Haplotaxis gordioides (Hartmann in Oken, 1819), previously cited as Haplotaxis gordioides (Hartmann, 1821).

\section{References}

Avel, M. (1959) Classe des Annélides Oligochètes. In: Grassé, P.-P. (Ed.), Traité de Zoologie. Anatomie, Systématique, Biologie. Masson et Cie, Paris, pp. 224-470.

Beddard, F.E. (1891) Anatomical description of two new genera of aquatic Oligochaeta. Transactions of the Royal Society of Edinburgh, 36 (Part 2), 11, 273-305. https://doi.org/10.1017/S0080456800037753

Beddard, F.E. (1895) A monograph of the order of Oligochaeta. Clarendon Press, Oxford, 769 pp. https://doi.org/10.5962/bhl.title.28557

Benham, W.B. (1890) An attempt to classify earthworms. The Quarterly Journal of Microscopical Science, 31, 201-315. https://doi.org/10.1242/jcs.s2-31.122.201

Brinkhurst, R.O. (1971) Phylogeny and classification Part 1. In: Brinkhurst, R.O \& Jamieson, B.G.M. (Eds.), Aquatic Oligochaeta of the World. Oliver \& Boyd, Edinburgh, pp. 165-177.

Brinkhurst, R.O. \& Jamieson, B.G.M. (1971) Aquatic Oligochaeta of the World. Oliver \& Boyd, Edinburgh, 860 pp.

Brinkhurst, R.O. (1982a) Oligochaeta. In: Synopsis and Classification of Living Organisms. Mc Graw-Hill Book Company, New York, pp. 50-61.

Brinkhurst, R.O. (1982b) Evolution in the Annelida. Canadian Journal of Zoology, 60, 1043-1059. https://doi.org/10.1139/z82-145

Brinkhurst, R.O. (1984) The position of the Haplotaxidae in the evolution of oligochaete annelids. Hydrobiologia, 115, 25-36. https://doi.org/10.1007/BF00027889

Brinkhurst, R.O. (1988) A taxonomic analysis of the Haplotaxidae (Annelida, Oligochaeta). Canadian Journal of Zoology, 66, 2243-2252.

https://doi.org/10.1139/z88-332

Černosvitov, L. (1936) Oligochaeten aus Südamerika. Systematische Stellung der Pristina flagellum Leidy. Zoologischer An- 
zeiger, 113, 75-84.

Chekanovskaya, O.V. (1981) Aquatic Oligochaeta of the USSR. Translated from Russian (Chekanovskaya 1962). Amerind Publishing, New Dehli, 513 pp.

Claparède, E. (1862) Recherches anatomiques sur les Oligochètes. Mémoires de la Société de Physique et d'Histoire naturelle de Genève, 16, 1-75.

Claus, C.F.W. (1872) Grundzüge der Zoologie, zum Gebrauche an Universitäten und höheren Lehranstalten. Leitfaden zur Einführung in das wissenschaftliche Studium der Zoologie. $2^{\text {nd }}$ Edition. N. G. Elwert'sche Universitäts-Buchhandlung, Marburg and Leipzig, $1170 \mathrm{pp}$. https://doi.org/10.5962/bhl.title.3783

Claus, C.F.W. (1880) Grundzüge der Zoologie, zum wissenschaftlichen Gebrauche. ${ }^{\text {th }}$ Edition. N. G. Elwert'sche UniversitätsBuchhandlung, Marburg and Leipzig, $882 \mathrm{pp}$. https://doi.org/10.5962/bhl.title.1113

Coates, K.A. (1986) Redescription of the oligochaete genus Propappus, and diagnosis of the new family Propappidae (Annelida: Oligochaeta). Proceedings of the Biological Society of Washington, 99, 417-428.

Cook, D.G. (1968). The genera of the family Lumbriculidae and the genus Dorydrilus (Annelida, Oligochaeta). Journal of Zoology, 156, 273-289. https://doi.org/10.1111/j.1469-7998.1968.tb04352.x

Corbi, J.J., Gorni, G.R. \& Correa, R.C. (2015) An evaluation of Allonais inaequalis Stephenson, 1911 (Oligochaeta: Naididae) as a toxicity test organism. Ecotoxicology \& Environmental Contamination, 10, 7-11. https://doi.org/10.5132/eec.2015.01.02

Dubois, A., Ohler, A. \& Pyron, R.A. (2021) New concepts and methods for phylogenetic taxonomy and nomenclature in zoology, exemplified by a new ranked cladonomy of recent amphibians (Lissamphibia). Megataxa, 5 (1), 1-738. https://doi.org/10.11646/megataxa.5.1.1

Ehrenberg (1831) Symbolae physicae, animalia evertebrata, exclusis insectis. Series prima cum tabularum decade prima. Phytozoa. Ex Officina Academica, venditur a Mittlero, Berlin, 70 pp.

Envall, I., Källersjö, M. \& Erséus, C. (2006) Molecular evidence for the non-monophyletic status of Naidinae (Annelida, Clitellata, Tubificidae). Molecular Phylogenetics and Evolution, 40, 570-584. https://doi.org/10.1016/j.ympev.2006.03.021

EoL [Encyclopedia of Life] (2021) Available from: https://eol.org (accessed 09 September 2021).

ERMS [European Register of Marine Species] (2021) Available from: http://www.marbef.org (accessed 09 September 2021)

Erséus, C. (1999) Parvidrilus strayeri, a new genus and species, an enigmatic interstitial clitellate from underground waters in Alabama. Proceedings of the Biological Society of Washington, 112, 327-337

Erséus, C., Envall, I., Marchese, M. \& Gustavsson, L. (2010b) The systematic position of Opistocystidae (Annelida, Clitellata) revealed by DNA data. Molecular Phylogenetics and Evolution, 54, 309-313. https://doi.org/10.1016/j.ympev.2009.09.037.

Erséus, C. \& Strehlow, D.R. (1986) Four new interstitial species of marine Oligochaeta representing a new family. Zoologica Scripta, 15, 53-60. https://doi.org/10.1111/j.1463-6409.1986.tb00208.x

Erséus, C., Wetzel, M.J., Gustavsson, L. (2008) ICZN rules—a farewell to Tubificidae (Annelida, Clitellata). Zootaxa, 1744 (1), $66-68$. https://doi.org/10.11646/zootaxa.1744.1.7

Erséus, C., Rota, E., Matamoros, L. \& De Wit, P. (2010a) Molecular phylogeny of Enchytraeidae (Annelida, Clitellata). Molecular Phylogenetics and Evolution, 57, 849-858. https://doi.org/10.1016/j.ympev.2010.07.005

Erséus, C., Williams, B.W., Horn, K.M., Halanych, K.M., Santos, S.R., James, S.W., Creuzé des Châtelliers, M. \& Anderson, F.E. (2020) Phylogenomic analyses reveal a Palaeozoic radiation and support a freshwater origin for clitellate annelids. Zoologica Scripta, 49, 614-640. https://doi.org/10.1111/zsc. 12426

Grube, A.E. (1850) Die Familien der Anneliden. Archiv für Naturgeschichte, 16, 249-364.

Harman, W.J. \& Loden, M.S. (1984) Capilloventer atlanticus gen. et sp. n., a member of a new family of marine Oligochaeta from Brazil. Hydrobiologia, 115, 51-54.

Holt, P.C. (1963) The systematic position of the Branchiobdellidae. American Zoologist, 3, 204.

Hrabě, S. (1984) Two atavistic characters of some Lumbriculidae and their importance for the classification of Oligochaeta. Hydrobiologia, 115, 15-17. https://doi.org/10.1007/BF00027892

International Commission of Zoological Nomenclature [ICZN] (1999) International code of zoological nomenclature [the Code]. Fourth edition. The International Trust for Zoological Nomenclature, c/o Natural History Museum, London. i-xxix, + 306 pp. [online version at https://www.iczn.org/the-code/the-international-code-of-zoological-nomenclature/the-codeonline/ (accessed 1 September 2021)

James, S. \& Davidson, S.K. (2012) Molecular phylogeny of earthworms (Annelida: Crassiclitellata) based on 28S, 18S and 16S gene sequences. Invertebrate Systematics, 26, 213-229.

https://doi.org/10.1071/IS11012 
Jamieson, B.G.M. (1978) Phylogenetic and phenetic systematics of the opisthoporous Oligochaeta (Annelida: Clitellata). Evolutionary Theory, 3, 195-233.

Jamieson, B.G.M. (1988) On the phylogeny and higher classification of the Oligochaeta. Cladistics, 4, 367-410. https://doi.org/10.1111/j.1096-0031.1988.tb00520.x

Jamieson, B.G.M (2006) Non-leech Clitellata, with contributions by Marco Ferraguti. In: Rouse, G. \& Pleijel, F. (Eds.), Reproductive Biology and Phylogeny of Annelida. Vol. 4. In: Jamieson, B.G.S. (Series Ed.), Reproductive Biology and Phylogeny. Science Publishers, Enfield, pp. 235-392.

Kasprzak, K. (1984) The previous and contemporary conceptions on phylogeny and systematic classifications of Oligochaeta (Annelida). Annales Zoologici, Warszawa, 38, 205-223.

Lamarck, J.B.P.A. (1818) Histoire naturelle des animaux sans vertèbres, présentant les caractères généraux et particuliers de ces animaux, leur distribution, leurs classes, leurs familles, leurs genres, et la citation des principales espèces qui s'y rapportent; précédée d'une introduction offrant la détermination des caractères essentiels de l'animal, sa distinction du végétal et des autres corps naturels; enfin, l'exposition des principes généraux de zoologie. Tome cinquième. Arachnides, Crustacés, Annélides, Cirrhipèdes. J. B. Baillière, Paris, 612 pp.

Lastočkin, D.A. (1921) Issledovanija po faune Ivanovo-Voznesenskoj gubernii. 3. Fauna Oligochaeta limicola rajona issledovanija. Izvestija Ivanovo-Voznesenskogo Politehničeskogo Instituta, 4, 70-77.

Livanow, N. (1905) Acanthobdella peledina Grube, 1851. Učenye Zapiski Kazanskogo Universiteta, 22, 1-271.

Magalhães, W.F., Hutchings, P., Oceguera-Figueroa, A., Martin, P., Schmelz, R.M., Wetzel, M., Wiklund, H., Maciolek, N.J., Kawauchi, G.Y. \& Williams, J.D. (2021) Segmented worms (Phylum Annelida): a celebration of twenty years of progress through Zootaxa and call for action on the taxonomic work that remains. Zootaxa, 4979 (1), 190-211. https://doi.org/10.11646/zootaxa.4979.1.18

Marotta, R., Ferraguti, M., Erséus, C. \& Gustavsson, L. (2008) Combined-data phylogenetics and character evolution of Clitellata (Annelida) using 18S rDNA and morphology. Zoological Journal of the Linnean Society, 154, 1-26. https://doi.org/10.1111/j.1096-3642.2008.00408.x

Martin, P. (2001) On the origin of the Hirudinea and the demise of the Oligochaeta. Proceedings of the Royal Society of London $B, 268,1089-1098$. https://doi.org/10.1098/rspb.2001.1616

Martínez-Ansemil, E., Creuzé des Châtelliers, M., Martin, P. \& Sambugar, B. (2012) The Parvidrilidae, a diversified groundwater family: description of six new species from southern Europe, and clues for its phylogenetic position within Clitellata (Annelida). Zoological Journal of the Linnean Society, 166, 530-558. https://doi.org/10.1111/j.1096-3642.2012.00857.x

Mayr, E. \& Ashlock, P.D. (1991) Principles of Systematic Zoology. $2^{\text {nd }}$ Edition. McGraw-Hill, New York, 475 pp.

Michaelsen, W. (1900) Oligochaeta. Das Tierreich, 10. Lieferung. R. Friedländer \& Sohn, Berlin, 575 pp.

Michaelsen, W. (1916) Ein eigentümlicher neuer Enchyträide der Gattung Propappus aus der Niederelbe. Verhandlungen des Naturwissenschaftlichen Vereins in Hamburg, 23, 51-55.

Michaelsen, W. (1919) Über die Beziehungen der Hirudineen zu den Oligochäten. Mitteilungen aus dem Hamburgischen zoologischen Museum und Institut, 36, 131-153.

Michaelsen, W. (1921) Zur Stammesgeschichte und Systematik der Oligochäten, insbesondere der Lumbriculiden. Archiv für Naturgeschichte, 86A, 130-141.

Michaelsen, W. (1928) Dritte Klasse der Vermes Polymera (Annelida), Clitellata = Gürtelwürmer. In: Krumbach, T. (Ed.), Handbuch der Zoologie, zweiter Band, zweite Hälfte: Vermes Polymera, Priapulida, Sipunculida, Echiurida, $1928-1934$. de Gruyter \& Co., Berlin and Leipzig, pp. 1-116.

Michaelsen, W. (1929) Zur Stammesgeschichte der Oligochäten. Zeitschrift für wissenschaftliche Zoologie, 134, $693-716$.

Ohtaka, A. \& Martin, P. (2011) Redescriptions of Spirosperma apapillatus and Embolocephalus nikolskyi (Annelida, Clitellata, Tubificinae) from Japan, with reference to distribution of papillate tubificines in Japanese freshwaters. Zoological Science, 28, 368-379.

https://doi.org/10.2108/zsj.28.368

Oken, L. (1819) Versammlung der Schweizer Naturforscher zu St. Gallen, vom 26, 27. und 28. Julius 1819. In: Oken, L. (Ed.), Isis oder Encyclopädische Zeitung von Oken. Litterarischer Anzeiger, Jena, Nr. XLV, Erster Band, Heft I-VI, pp. 178-179.

Righi, G. \& Varela, M.E. (1983) Narapa bonettoi, gen. nov. sp. nov. (Oligochaeta, Narapidae, fam. nov.) de agua doce da Argentina. Revista de la Asociacion de Ciencias Naturales del Litoral, 14, 7-15. https://doi.org/10.14409/natura.v1i14.3409

Ruggiero, M.A., Gordon, D.P., Orrell, T.M., Bailly, N., Bourgoin, T., Brusca, R.C., Cavalier-Smith, T., Guiry, M.D. \& Kirket, P.M. (2015a) A higher level classification of all living organisms. PLoS ONE, 10 (4), e 0119248, 1-60. https://doi.org/10.1371/journal.pone.0119248

Ruggiero, M.A., Gordon, D.P., Orrell, T.M., Bailly, N., Bourgoin, T., Brusca, R.C., Cavalier-Smith, T., Guiry, M.D. \& Kirket, P.M. (2015b) Correction: A Higher Level Classification of All Living Organisms. PLoS ONE, 10 (6), e0130114, 1-54. https://doi.org/10.1371/journal.pone.0130114

Siddall, M.E., Apakupakul, K., Burreson, E.M., Coates, K.A., Erséus, C., Gelder, S.R., Källersjö, M. \& Trapido-Rosenthal, H. (2001) Validating Livanow: molecular data agree that leeches, branchiobdellidans and Acanthobdella peledina form a 
monophyletic group of oligochaetes. Molecular Phylogenetics and Evolution, 21, 346-351.

https://doi.org/10.1006/mpev.2001.1021

Smith, F. \& Green, B.R. (1919) Descriptions of new African earthworms, including a new genus of Moniligastridae. Proceedings of the United States National Museum, Washington, 55, 145-166. https://doi.org/10.5479/si.00963801.55-2263.145

Stephenson, J. (1930) The Oligochaeta. Clarendon Press, Oxford, 978 pp.

Struck, T., Paul, C., Hill, N., Hartmann, S., Hösel, C., Kube, M., Lieb, B., Meyer, A., Tiedemann, R., Purschke, G. \& Bleidorn, C. (2011) Phylogenomic analyses unravel annelid evolution. Nature, 471, 95-98. https://doi.org/10.1038/nature09864

Timm, T. (1981) On the origin and evolution of aquatic Oligochaeta. Eesti NSV Teaduste Akadeemia Toimetised, Bioloogia, 30 , $174-181$

Timm, T. (2021) World distribution of the aquatic Oligochaeta. PlutoF. Tartu. Accessed via GBIF.org. Available from: https:// doi.org/10.15468/2ywn3u (accessed 09 September 2021)

Timm, T. \& Martin, P. (2015) Chapter 21. Clitellata: Oligochaeta. In: Thorp, J.H. \& Rogers, D.C. (Eds.), Thorp and Covich's Freshwater Invertebrates. Vol. I. Ecology and General Biology. Academic Press, Elsevier, Waltham, Massachusetts, pp. 529-549. https://doi.org/10.1016/B978-0-12-385026-3.00021-8

Ude, H. (1929) Oligochaeta. Die Tierwelt Deutschlands und der angrenzenden Meeresteile. Oligochaeta. Verlag von Gustav Fischer, Jena, $132 \mathrm{pp}$.

Udekem, J.d‘ (1855) Nouvelle classification des Annélides sétigères abranches. Bulletins de l'Académie Royale Belgique, classe des sciences, 22, 533-555.

Van Haaren, T., Martin, P. \& Dubois, A. (2021) Authorship and date of five family-series nomina in Oligochaeta (Annelida): Lumbricidae, Naididae, Enchytraeidae, Tubificidae and Lumbriculidae. Bionomina, 21, 140-145. https://doi.org/10.11646/bionomina.21.1.10

Vejdovský, F. (1884) System und Morphologie der Oligochaeten. Franz Řivnáč, Prag, 166 pp.

Wikispecies (2021) Available from: https://species.wikimedia.org (accessed 09 September 2021)

WoRMS Editorial Board (2021) World Register of Marine Species. VLIZ Vlaams Instituut voor de Zee. Available from: http:// www.marinespecies.org (accessed 09 September 2021)

https://doi.org/10.14284/170 